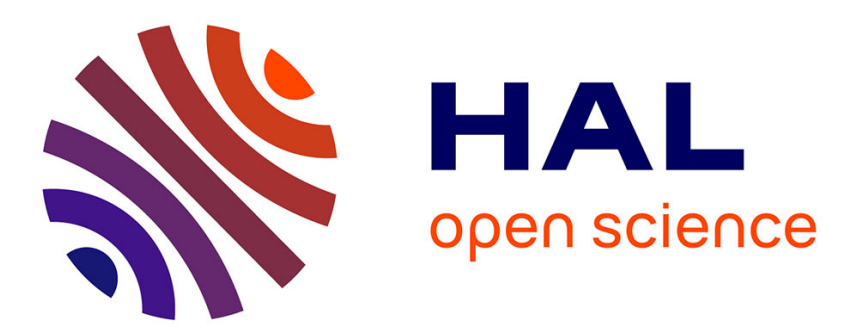

\title{
A few effective trees hiding a forest of unprotected marine protected areas
}

Joachim Claudet, Charles Loiseau, Marta Sostres, Mirta Zupan

\section{To cite this version:}

Joachim Claudet, Charles Loiseau, Marta Sostres, Mirta Zupan. A few effective trees hiding a forest of unprotected marine protected areas. One Earth, 2020, 2 (4), pp.380-384. 10.1016/j.oneear.2020.03.008 . hal-03034387

\section{HAL Id: hal-03034387 https://hal.science/hal-03034387}

Submitted on 1 Dec 2020

HAL is a multi-disciplinary open access archive for the deposit and dissemination of scientific research documents, whether they are published or not. The documents may come from teaching and research institutions in France or abroad, or from public or private research centers.
L'archive ouverte pluridisciplinaire HAL, est destinée au dépôt et à la diffusion de documents scientifiques de niveau recherche, publiés ou non, émanant des établissements d'enseignement et de recherche français ou étrangers, des laboratoires publics ou privés. 
Title: A few effective trees hiding a forest of unprotected marine protected areas

Running head: Shedding light on marine conservation efforts

Authors: Joachim Claudet ${ }^{1^{*}}$, Charles Loiseau ${ }^{1}$, Marta Sostres ${ }^{1}$, Mirta Zupan ${ }^{2}$

\section{Affiliations:}

$5 \quad{ }^{1}$ National Center for Scientific Research, PSL Université Paris, CRIOBE, USR 3278 CNRS-EPHE-UPVD, Maison des Océans, 195 rue Saint-Jacques 75005 Paris, France. *Correspond author.

${ }^{2}$ Royal Belgium Institute of Natural Science, Rue Vautier 29, 1000 Brussels, Belgium

One sentence summary: Our current efforts at managing human uses of nature at sea are not sufficient to deliver tangible benefits for biodiversity.

Abstract: Ocean health is critical for achieving sustainable development but is threatened by multiple stressors. Member States Parties to the Convention on Biological Diversity agreed to protect $10 \%$ of their waters by 2020. The scientific evidence supporting the use of marine protected areas (MPAs) to conserve biodiversity stems primarily from knowledge concerning fully protected areas but at present, most of what is being established are partially protected areas. Here, we assess the protection levels of the 1062 Mediterranean MPAs. While $6.01 \%$ of the Mediterranean is covered by an MPA, $85 \%$ of these MPAs do not impose regulations stronger inside than outside. Full and high levels of protection, the most effective for biodiversity conservation, represent only $0.23 \%$ of the basin and are unevenly distributed across political and eco-regions. Our current efforts are insufficient at managing human uses of nature and protection levels should be increased to deliver tangible benefits for biodiversity conservation.

Key-words: conservation; UN Sustainable Development Goals; Convention on Biological Diversity; Mediterranean Sea; marine policy

\section{Main text:}

\section{Introduction}

The ocean is critical for achieving sustainable development of human society as a whole. Many Sustainable Development Goals (SDGs) may not be realized without achieving SDG 14 for healthy ocean ${ }^{1}$. However, oceans are threatened by multiple stressors; direct exploitation of organisms, mainly fishing, being the most impactful driver ${ }^{2}$. While there is an urgent need to modify human behavior to allow sustainable development pathways ${ }^{3,4}$, mitigating strategies still need to be put into practice. Marine protected areas (MPAs) are an effective spatial, ecosystem-based management tool in this respect ${ }^{5}$ and Member States Parties to the Convention on Biological Diversity (CBD) agreed to cover $10 \%$ of their Economic Exclusive Zones (EEZs) by MPAs by $2020^{6}$. The SDG target 14.5 is of exactly the same figure. We ask here whether this led to effective conservation strategies or if Member States had misguided the original aim of the target, which is to deliver conservation outcomes.

While the science supporting the usefulness of MPAs was only based on fully protected areas ${ }^{7,8}$, where all extractive activities are forbidden, most recently established MPAs to meet the CBD Aïchi target 11 are partially protected ${ }^{9,10}$. Partially protected areas are often preferred over fully protected areas as they can satisfy access to a boarder range of users. However, allowed uses, even if regulated, often concentrate inside such areas ${ }^{11,12}$ with potentially higher detrimental impacts on biodiversity ${ }^{13}$. 
A recently developed regulation-based classification system for MPAs allows to group MPAs according to the potential impacts on species and habitats of allowed uses ${ }^{14}$. Its global application on published literature on MPA effectiveness showed that, on average, only fully and highly protected areas, allowing only infrequent use of some types of non-industrial, highly selective, low impact, recreational, commercial or subsistence fishing gears, could deliver ecological benefits ${ }^{15}$. Protection levels are therefore a good indicator of MPA performance.

Here, focusing on the Mediterranean Sea, which is both a global hotspot for biodiversity ${ }^{16}$ and human pressure ${ }^{17}$, and features an extensive system of MPAs ${ }^{18}$, we critically assess whether conservation efforts are appropriately strategized to deliver ecological benefits.

\section{Results and Discussion}

We complied information from MAPAMED ${ }^{19}$, the most complete database on MPAs for the Mediterranean. We worked at the zone level in case of multiple-zone MPAs and reviewed the management plans and legal texts for the 1062 existing MPAs (or 1346 zones) to classify them using 55 the regulation-based classification system ${ }^{14}$. All 1062 MPAs included in our study are validated by Countries or focal points of the Barcelona Convention (UNEP Regional Sea Convention), thus counting toward international biodiversity conservation targets. When several zones (or MPAs, or designations) were overlapping, only the one conferring the strongest protection level were kept.

We found that $6.01 \%$ of the Mediterranean Sea is covered with an MPA. This situation is well representative of the global one with the United Nations Environment Program's World Conservation Monitoring Centre (WCMC) and the International Union for the Conservation of Nature (IUCN) reporting $6.97 \%$ of global ocean protection as of $2017^{10}$. In the Mediterranean Sea, more than a fifth of those are not managed or established as no management plan or legal text could be found, and two thirds don't have any restrictions on activities that can impact biodiversity (Figure 1). Hence, for $85 \%$ of the Mediterranean MPAs there is no difference in regulations between the inside and the outside.

Full and high protection, those levels of protection known to deliver ecological benefits ${ }^{15}$, cover only $0.23 \%$ of the Mediterranean Sea, representing only $3.42 \%$ of what is being protected. As the CBD $10 \%$ target of countries' EEZs was designed with the aim to reaching conservation outcomes, they should concern mostly, if not only, those protection levels. 

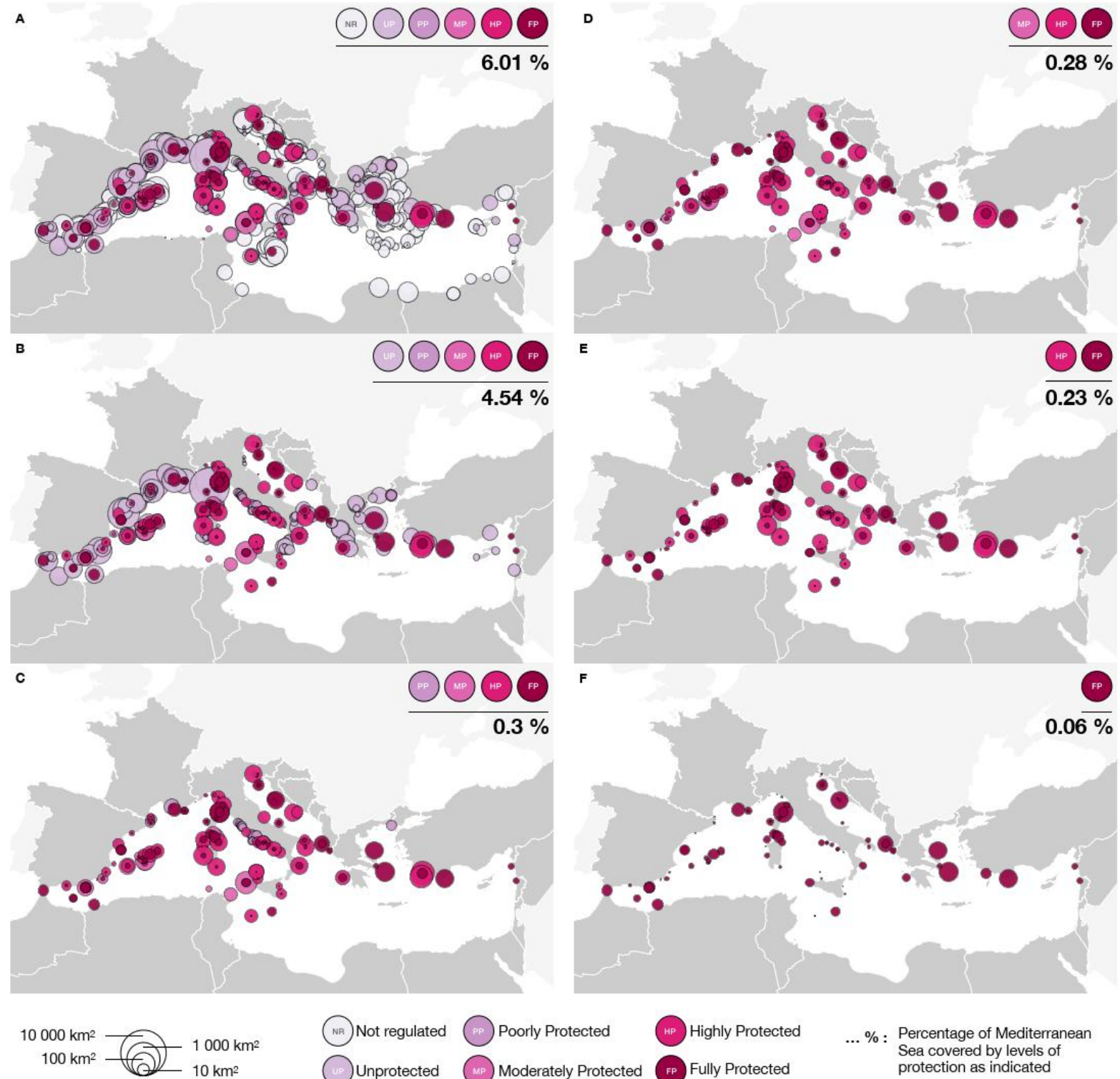

NR Not regulated Poorly Protected
Unprotected Moderately Protected

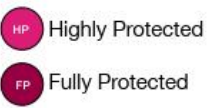

$\ldots \%$ : Percentage of Mediterranean Sea covered by levels of

Figure 1: Coverage the different levels of protection in the Mediterranean Sea.

The overall effort is greatly unbalanced since close to $97 \%$ of total marine protection, and $80 \%$ and $63 \%$ of full and high protection, respectively, lay in European Union's waters (Figure 2A). In the European union, full and high protection cover $0.15 \%$ of countries' EEZs while it is less than half in non-European countries. Countries protecting a large part of their EEZ most of the time benefit from large MPAs with low levels of protection (Figure 2B). 

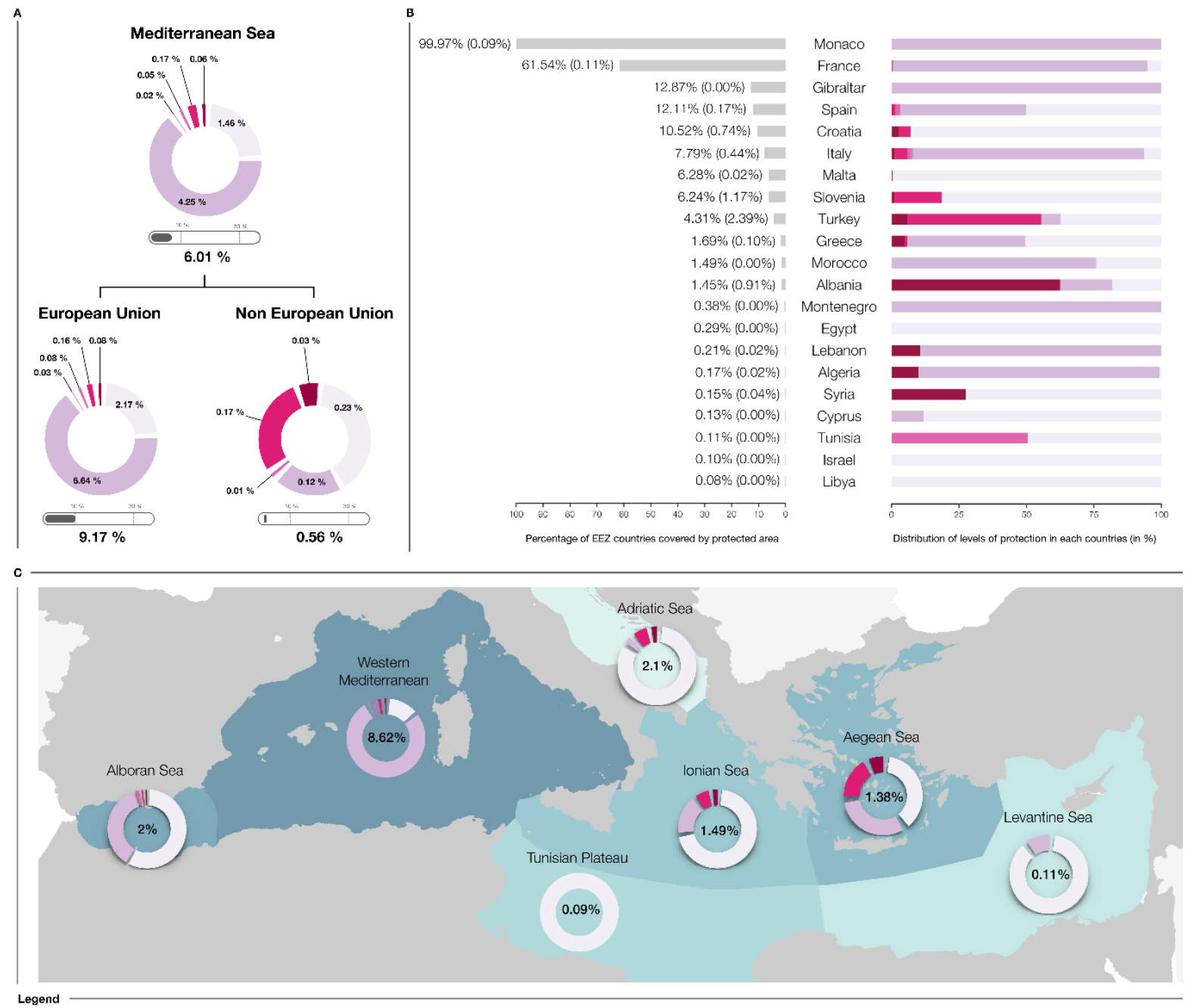

Figure 2: Distribution of protection levels $(A)$ in the Mediterranean Sea; $(B)$ per country, percentage in parenthesis are the percentage of countries' EEZ covered by fully and highly protected areas; (C) by Mediterranean marine ecoregions.

The CBD Aïchi target 11 stipulates that protected areas have to be "ecologically representative" ${ }^{6}$. In the Mediterranean, marine ecoregions ${ }^{20}$ are not equally protected (Figure $2 \mathrm{C}$ ). The Western Mediterranean is by far the most protected $(8.62 \%)$, but only $1.89 \%$ of what is being protected is done so by full or high protection levels. The Adriatic and Alboran Seas are the second most protected marine ecoregions. Aegan and Ionian Seas have very similar coverage of protection but full and high protection coverage vary up to three orders of magnitude. The Levantine Sea and the Tunisian plateau are the least protected ecoregions in the Mediterranean.

Our results suggest that much of the Mediterranean Sea is not protected, and more than $85 \%$ of what is supposed to be protected do not convey regulations strict enough to confer any ecological benefit ${ }^{15}$. As in other parts of the world, where too lose regulations cannot deliver ecological outcomes $13,21,22$, or where protected areas are not properly resourced or managed ${ }^{23,24}$, it is important to ensure that the race to meet key biodiversity targets does not lead us to a false sense of security about appropriate actions being undertaken ${ }^{25,26}$. We believe that classifying MPAs according to their protection levels as we did here is a much needed step towards shedding light on our actual insufficient efforts at managing human uses of nature ${ }^{27}$. We hope this will translate into more will from our policy-makers to establish and appropriately manage MPAs with protection levels that are able to deliver tangible benefits for biodiversity conservation. 


\section{Methods}

Legally binding MPAs were retrieved from MAPAMED ${ }^{19}$. Fishing Restricted Areas $(n=7)$, Specially Protected Area of Mediterranean Importance $(n=34)$ and Particularly Sensitive Sea Area $(n=1)$ were removed. In the case of non-strictly marine protected areas $(n=46)$, only the marine part was kept. In the case of multiple-zone MPAs ( $n=75)$, MPAs were considered at the zone level. We then collected information on allowed or prohibited activities from legal texts, management plans and personal communication with MPA managers, using all needed native languages. Specific information from Natura 2000 sites was also obtained from the European Environment Agency official website (https://www.eea.europa.eu/data-and-maps/data/natura-10), but we cross-referenced it as in many cases it was outdated. We then classified all MPAs, or zones in the case of multiple-zone MPAs, using the regulation-based classification system ${ }^{14}$. We thus obtained a protection level for each of the 1062 MPAs (or 1346 zones). In the case of MPAs with no legal text or management plan establishing regulations, we assigned the MPAs to a non-regulated category.

Existing georeferenced information in MAPAMED was used. When missing, in multiple instances, and almost for all zoning schemes in the case of multiple-zone MPAs, additional information was obtained as detailed above for the regulations. To avoid overestimating the total area covered by protection we removed overlapping area, keeping only those conferring the strongest levels of protection for each overlapping layers. Exclusive Economic Zones were retrieved from Flanders Marine Institute, Maritime Boundaries Geodatabase, version 10 (2018; Available online at http://www.marineregions.org/. https://doi.org/10.14284/319. Mediterranean eco-regions were retrieved from ${ }^{20}$. All analyses were conducted using QGIS v.2.18.0 and $\mathrm{R}^{28}$.

\section{Acknowledgements}

120 We wish to thank MedPAN and RAC-SPA, and especially Bruno Meola and Reda Neveu, for their management of the MAPAMED database. We also thank Barbara Horta e Costa, Karim Erzini and Emanuel Gonçalves for the role they played in the development of the Regulation-Based Classification System.

\section{Funding}

This work did not receive specific funding.

\section{Author contributions}

J.C. designed the study. M.S., M.Z. and C.L. compiled the data. J.C., C.L. and M.S. analyzed the data. J.C. and C.L. produced the figures. J.C. wrote the manuscript. All authors approved the manuscript.

\section{References}

130 1. Singh, G. G. et al. A rapid assessment of co-benefits and trade-offs among Sustainable Development Goals. Mar. Policy 93, 223-231 (2018).

2. Díaz, S. et al. Summary for policymakers of the global assessment report on biodiversity and ecosystem services of the Intergovernmental Science-Policy Platform on Biodiversity and Ecosystem Services. (2019).

135 3. Butchart, S. H. M. M. et al. Global biodiversity: Indicators of recent declines. Science (80-. ). 328, 1164-8 (2010).

4. Nash, K. L. et al. Planetary boundaries for a blue planet. Nat. Ecol. Evol. 1, 1625-1634 (2017).

5. Lubchenco, J. \& Grorud-Colvert, K. Making waves: The science and politics of ocean 
protection. Science (80-. ). 350, $382 \mathrm{LP}-383$ (2015).

140 6. CBD (Convention on Biological Diversity). COP 10 Decision X/2. Strategic Plan for Biodiversity 2011-2020. (2010). Available at: https://www.cbd.int/decision/cop/?id=12268.

7. Claudet, J. et al. Marine reserves: Size and age do matter. Ecol. Lett. 11, 481-489 (2008).

8. Lester, S. E. et al. Biological effects within no-take marine reserves: A global synthesis. Mar. Ecol. Prog. Ser. 384, 33-46 (2009).

9. Claudet, J. Six conditions under which MPAs might not appear effective (when they are). ICES J. Mar. Sci. 75, (2018).

10. Sala, E. et al. Assessing real progress towards effective ocean protection. Mar. Policy 91, 1113 (2018).

11. Zupan, M. et al. How good is your marine protected area at curbing threats? Biol. Conserv. 221, 237-245 (2018).

12. Mazaris, A. D. et al. Threats to marine biodiversity in European protected areas. Sci. Total Environ. 677, 418-426 (2019).

13. Dureuil, M., Boerder, K., Burnett, K. A., Froese, R. \& Worm, B. Elevated trawling inside protected areas undermines conservation outcomes in a global fishing hot spot. Science (80-. ). 1407, 1403-1407 (2018).

14. Horta e Costa, B. et al. A regulation-based classification system for Marine Protected Areas (MPAs). Mar. Policy 72, 192-198 (2016).

15. Zupan, M. et al. Marine partially protected areas: drivers of ecological effectiveness. Front. Ecol. Environ. 16, 381-387 (2018).

16. Coll, M. et al. The biodiversity of the Mediterranean Sea: Estimates, patterns, and threats. PLoS One 5, e11842- (2010).

17. Myers, N., Mittermeier, R. A., Mittermeier, C. G., da Fonseca, G. A. B. \& Kent, J. Biodiversity hotspots for conservation priorities. Nature 403, 853-858 (2000).

18. Amengual, J. \& Alvarez-Berastegui, D. A critical evaluation of the Aichi Biodiversity Target 11 and the Mediterranean MPA network, two years ahead of its deadline. Biol. Conserv. 225, 187-196 (2018).

19. MedPAN/SPARAC-MAPAMED. Marine Protected Areas in the Mediterranean. (2018). Available at: https://www.mapamed.org/.

20. Spalding, M. D. et al. Marine Ecoregions of the World: A Bioregionalization of Coastal and Shelf Areas. Bioscience 57, 573 (2007).

21. Magris, R. A. \& Pressey, R. L. Marine protected areas: Just for show? Science (80-. ). 360, 723 LP - 724 (2018).

22. Cramp, J. E., Simpfendorfer, C. A. \& Pressey, R. L. Beware silent waning of shark protection. Science (80-. ). 360, 723 LP - 723 (2018).

175 23. Rife, A. N., Erisman, B., Sanchez, A. \& Aburto-Oropeza, O. When good intentions are not enough...Insights on networks of 'paper park' marine protected areas. Conserv. Lett. 6, 200212 (2013).

24. Gill, D. A. et al. Capacity shortfalls hinder the performance of marine protected areas globally. 
Nature 543, 665-669 (2017).

18025 . Lemieux, C. J. et al. How the race to achieve Aichi Target 11 could jeopardize the effective conservation of biodiversity in Canada and beyond. Mar. Policy 99, 312-323 (2019).

26. Agardy, T., Claudet, J. \& Day, J. C. 'Dangerous Targets' revisited: Old dangers in new contexts plague marine protected areas. Aquat. Conserv. Mar. Freshw. Ecosyst. 26, 7-23 (2016).

27. Costello, M. J. \& Ballantine, B. Biodiversity conservation should focus on no-take Marine Reserves: 94\% of Marine Protected Areas allow fishing. Trends Ecol. Evol. 30, 507-509 (2015).

28. R Core Team. R: A Language and Environment for Statistical Computing. Vienna, Austria: R Foundation for Statistical Computing; 2017. R Foundation for Statistical Computing. ... Freely Available on the Internet At: Http://Www. R-Project. ... (2017). 


\section{Supplementary material}

Table 1: Protected area $\left(\mathrm{km}^{2}\right)$ by protection level and per country

\begin{tabular}{|c|c|c|c|c|c|c|c|c|c|c|c|}
\hline \multirow[b]{2}{*}{ Country } & \multirow[b]{2}{*}{$\begin{array}{l}\text { Member of } \\
\text { EU }\end{array}$} & \multirow[b]{2}{*}{ EEZ area } & \multirow[b]{2}{*}{ Number of MPAs } & \multirow[b]{2}{*}{ Number of zones } & \multicolumn{7}{|c|}{ Protected area } \\
\hline & & & & & Total & Fully Protected & Highly Protected & Moderately Protected & Poorly protected & Unprotected & Not Reported \\
\hline Albania & No & 11152.0 & 9 & 14 & 161.9 & 101.07 & 0 & 0 & 0 & 31.15 & 29.67 \\
\hline Algeria & No & 128905.5 & 4 & 6 & 220.5 & 21.82 & 0 & 0 & 0 & 197.11 & 1.52 \\
\hline Croatia & Yes & 55866.5 & 267 & 304 & 5876.8 & 161.63 & 250.2 & 0 & 0.54 & 0 & 5464.42 \\
\hline Cyprus & Yes & 98118.5 & 8 & 8 & 129.7 & 0 & 0 & 0 & 0 & 15.49 & 114.17 \\
\hline Egypt & No & 169411.6 & 6 & 6 & 485.0 & 0 & 0 & 0 & 0 & 0 & 485 \\
\hline France & Yes & 88565.8 & 85 & 102 & 54505.0 & 79.127 & 15.27 & 122.27 & 101.86 & 51459.761 & 2726.76 \\
\hline Gibraltar & No & 426.3 & 1 & 1 & 54.9 & 0 & 0 & 0 & 0 & 54.85 & 0 \\
\hline Greece & Yes & 494594.5 & 149 & 160 & 8382.8 & 408.264 & 75.293 & 0 & 18.13 & 3655.89 & 4225.26 \\
\hline Israel & No & 27753.2 & 10 & 10 & 26.5 & 0 & 0 & 0 & 0 & 0 & 26.5 \\
\hline Italy & Yes & 539059.9 & 279 & 414 & 42002.9 & 431.75 & 1957.65 & 644.03 & 303.31 & 35922.01 & 2744.17 \\
\hline Lebanon & No & 19265.9 & 2 & 2 & 39.9 & 4.17 & 0 & 0 & 0 & 35.69 & 0 \\
\hline Libya & No & 357297.6 & 2 & 2 & 300.3 & 0 & 0 & 0 & 0 & 0 & 300.32 \\
\hline Malta & Yes & 55417.4 & 30 & 30 & 3479.6 & 12.98 & 0 & 0 & 0 & 0 & 3466.61 \\
\hline Monaco & No & 283.2 & 3 & 3 & 283.1 & 0.02 & 0.23 & 0 & 0 & 282.889 & 0 \\
\hline Montenegro & No & 7466.1 & 2 & 2 & 28.1 & 0 & 0 & 0 & 0 & 28.1 & 0 \\
\hline Morocco & No & 18776.7 & 2 & 2 & 278.9 & 0 & 0 & 0 & 0 & 211.5 & 67.39 \\
\hline Slovenia & Yes & 193.2 & 15 & 17 & 12.1 & 0.12 & 2.14 & 0 & 0 & 0 & 9.8 \\
\hline Spain & Yes & 261168.8 & 173 & 226 & 31628.1 & 121.723 & 323.42 & 524.68 & 45.066 & 14742.8167 & 15870.43 \\
\hline Syria & No & 10194.2 & 2 & 2 & 15.4 & 4.24 & 0 & 0 & 0 & 0 & 11.14 \\
\hline Tunisia & No & 100550.9 & 4 & 4 & 110.0 & 0 & 0 & 55.47 & 0 & 0 & 54.52 \\
\hline Turkey & No & 72414.9 & 12 & 31 & 3123.7 & 175.93 & 1557.66 & 0 & 0 & 222.1 & 1168.04 \\
\hline TOTAL & & 2516882.5 & 1062 & 1346 & 151145.1 & 1522.8 & 4181.9 & 1346.5 & 468.9 & 106859.4 & 36765.7 \\
\hline
\end{tabular}


Table 2: Protected area $\left(\mathrm{km}^{2}\right)$ by protection level and per eco-region

\begin{tabular}{|c|c|c|c|c|c|c|c|c|c|c|}
\hline \multirow[b]{2}{*}{ Ecoregion } & \multirow[b]{2}{*}{ Ecoregion area } & \multirow[b]{2}{*}{ Number of MPAs } & \multirow[b]{2}{*}{ Number of zones } & \multicolumn{7}{|c|}{ Protected area } \\
\hline & & & & Total & Fully Protected & Highly Protected & Moderately Protected & Poorly protected & Unprotected & Not Reported \\
\hline Adriatic Sea & 353081.5 & 340 & 388 & 7416.8 & 168.03 & 461.57 & 0 & 0.54 & 202.19 & 6584.47 \\
\hline Aegean Sea & 610233.3 & 127 & 153 & 8394.51 & 576.18 & 1557.66 & 0 & 18.13 & 2844.33 & 3398.21 \\
\hline Alboran Sea & 352546.6 & 42 & 55 & 7048.45 & 51.553 & 23.16 & 96.52 & 0 & 2649.237 & 4227.98 \\
\hline Ionian Sea & 455011.8 & 107 & 128 & 6788.707 & 131.714 & 412.013 & 0 & 0 & 1120.21 & 5124.77 \\
\hline Levantine Sea & 1118761.7 & 32 & 32 & 1180.84 & 8.41 & 0 & 0 & 0 & 130.19 & 1042.24 \\
\hline Tunisian Plateau/Gulf of Sidra & 1077854.3 & 7 & 15 & 986.77 & 0.79 & 39.85 & 0 & 0 & 0 & 946.13 \\
\hline Western Mediterranean & 1383324.4 & 405 & 572 & 119234.483 & 565.567 & 1687.61 & 1249.93 & 450.236 & 99839.22 & 15441.92 \\
\hline
\end{tabular}

